\title{
SOBRE UM PARÁGRAFo de Michel FouCAULT: RESPOSTA A MUITAS QUESTŌES?
}

\author{
Heliana de Barros Conde Rodrigues*
}

\section{Resumo}

Em "Resposta a uma questão", artigo-réplica a perguntas encaminhadas a Michel Foucault pela revista Esprit, um parágrafo concernente às relações entre a constituição da medicina clínica e a Revolução Francesa nos parece, ainda hoje, paradigmático do modo de pensar foucaultiano. O presente ensaio dele parte, no intuito de distinguir a perspectiva foucaultiana daquelas ligadas à História das Mentalidades e à Sociologia do Conhecimento. Em seguida, usa-o como ferramenta analítica de uma recente polêmica, relativa a uma investigação que se propõe a mapear o cérebro de "adolescentes infratores". Avalia-se que o parágrafo mencionado faculta entender de modo singular o repúdio de uma parcela da intelectualidade e da militância ao projeto de pesquisa em pauta. Com isso, a "Resposta a uma questão" se amplia a uma resposta a muitas questôes, especialmente ao que se pode entender por defesa dos Direitos Humanos no campo dos saberes e regimes de verdade.

Palavras-chave: Foucault; Direitos Humanos; política; discursos científicos.

\section{Abstract}

About a PARAgraph of Michel Foucault: ANSWER tO MANY QUESTIONS?

In "Response to a question", a Michel Foucault's paper in which he answers questions sent by the journal Esprit, a paragraph concerning the relationship between the formation of clinical medicine and the French Revolution seems to be, even today, paradigmatic of the Foucaultian way of thinking. This essay is based on that paragraph, in order to distinguish Foucault'sperspective from the History of Mentalities and the Sociology of Knowledge. The essay uses the same paragraph as a tool to analyze a recent controversy, linked to an investigation that intends to map the brains of "juvenile delinquents". We think that the aforementioned paragraph allows us to understand in a unique way the rejection that a parcel of the intellectuality and the militancy

* Professora-adjunta do Departamento de Psicologia Social e Institucional, Instituto de Psicologia da Universidade do Estado do Rio de Janeiro (UERJ). 
directed to that research project. In this sense, "Response to a question" is extended to answers to many questions, especially to the way one can understand the defense of Human Rights in the field of knowledge and regimes of truth.

Keywords: Foucault; Human Rights; politics; scientific discourses.

\section{INTRODUÇÃO}

Os escritos de Michel Foucault tornaram-se referência para consideráveis parcelas da intelectualidade e militância brasileiras, que lhes demandam respostas a inúmeras questões do presente: das relações familiares aos desmandos institucionais; da proliferação das sexualidades não-canônicas aos dispositivos de segurança; da ação dos especialistas ao estatuto da infância; das políticas públicas às lutas libertárias de variados matizes. Tudo sugere um recurso à teoria como "caixa de ferramentas" (Foucault \& Deleuze, 1979: 71); porém as redes da "função autor" (Foucault, [1969] 1992) atuam em favor de discussões sobre consistência interna, periodização etc da "obra" de Foucault - em suma, de uma recensão prévia a qualquer efetiva serventia de seus martelos, alicates e torqueses.

Sem a pretensão de escapar por completo a tais circunstâncias, o presente ensaio não aspira a esses exercícios hagiográficos, mas à utilização do discurso foucaultiano como "óculos dirigidos para fora" (Foucault \& Deleuze, 1979: 71). Para tanto, um parágrafo de um texto dito "menor", de uma etapa eventualmente avaliada como "superada" - a arqueologia do saber -, nos servirá de ferramenta para apreciar uma polêmica contemporânea relativa a uma investigação voltada a mapear o cérebro de "adolescentes homicidas" ${ }^{1}$, que pôs em tela de juízo as relações entre as pesquisas desenvolvidas na Universidade e os Direitos Humanos.

\section{UMA QUESTÃO-MULTIPLICIDADE}

Em 1968, Foucault recebe de Esprit onze perguntas enviadas pelos leitores do periódico. Opta por responder apenas à última, assim formulada:

Um pensamento que introduz a sujeição ao sistema e a descontinuidade na história do espírito não tira todo o fundamento a uma intervenção política progressista? Não acaba no dilema seguinte: ou a aceitação do sistema; ou o apelo ao acontecimento selvagem, à irrupção de uma violência exterior, única capaz de sacudir o sistema? (Foucault, 1972: 57). 
O artigo-réplica, intitulado "Resposta a uma questão"2, constitui uma espécie de ante-sala ${ }^{3}$ do que virá a ser, no ano seguinte, $A$ arqueologia do saber. Nossa intenção não é expô-lo em minúcias. Basta mencionar que, de início, Foucault recusa o singular associado a "sistema" e a "descontinuidade", dizendo-se "pluralista”. E que logo identifica seu principal adversário, condensado na expressão "história do espírito": o apelo, na análise dos discursos, à unidade de uma arquitetura formal, quer histórico-transcendental quer empírico-psicológica, ao qual contrapõe uma perspectiva voltada a identificar formaçôes discursivas e suas eventuais descontinuidades; ou melhor, a apreender, quanto aos discursos, regras de formação, transformação e correlação (com outros discursos e com o nãodiscursivo).

Porém o alvo de Foucault é a interrogação política, por ele assim caracterizada: "Existe atualmente um problema que não deixa de ter importância para a prática política: o do estatuto, das condições de exercício, do funcionamento, da institucionalização dos discursos científicos" (Foucault, 1972: 73). Partindo de tal "deixa", podemos nos dirigir ao parágrafo que constitui o cerne de nossa atenção.

Ali, manejando um exemplo, Foucault indaga qual seria a relação entre a formação de um discurso - no caso, o discurso clínico que caracterizou a medicina do começo do século XIX a nossos dias ${ }^{4}$ - e certo número de acontecimentos políticos - agrupados sob o rótulo "Revolução Francesa". Após formular (e rejeitar) duas hipóteses - às quais voltaremos -, apresenta a que orienta suas pesquisas:

Se há [...] uma ligação entre a prática política e o discurso médico, não é [...] porque esta prática mudou, primeiro, a consciência dos homens, sua maneira de perceber as coisas ou de perceber o mundo, depois finalmente a forma de seu conhecimento e o conteúdo de seu saber; não é também porque esta prática se refletiu de início de maneira mais ou menos clara e sistemática em conceitos, noçôes ou temas que foram, em seguida, importados pela medicina; é de uma maneira muito mais direta: a prática política transformou não o sentido nem a forma do discurso, mas suas condições de emergência, de inserção e de funcionamento; ela transformou o modo de existência do discurso médico (Foucault, 1972: 74-75).

O parágrafo prossegue com um detalhamento desse modo de existência:

[...] novos critérios para designar aqueles que recebem estatutariamente o direito de ter um discurso médico; novo corte do objeto médico pela aplicação de uma outra escala de observação, que se superpõe à primeira sem apagá-la (a 
doença observada estatisticamente ao nível de uma população); novo estatuto da assistência que cria um espaço hospitalar de observação e de intervenção médicas (espaço que é organizado aliás segundo um princípio econômico, visto que o doente, beneficiário dos cuidados, deve retribuí-los pela lição médica que ele dá: ele paga o direito de ser socorrido pela obrigação de ser olhado e isso até a morte, inclusive); nova forma de registro, de conservação, de acumulação, de difusão e de ensinamento do discurso médico (que não deve mais manifestar a experiência do médico, mas constituir antes um documento sobre a doença); novo funcionamento do discurso médico no sistema de controle administrativo e político da população (a sociedade, enquanto tal, é considerada, e "tratada", segundo as categorias da saúde e do patológico) (Foucault, 1972: 75)

Duas hipóteses são afastadas: a tributária da história das mentalidades, segundo a qual a prática política se expressa na consciência dos homens e, por derivação, na forma que seu conhecimento adquire; e a articulada à sociologia do conhecimento, de acordo com a qual a prática política se reflete em conceitos políticos e estes, por transposição ou analogia, em conceitos de saberes outros (médico, psicológico, jurídico etc.). Embora não redundem necessariamente em afirmações descabidas - consideremos a substituição da preocupação com a salvação pela preocupação com a saúde, ligada à primeira hipótese, e o abandono do princípio classificatório das doenças em proveito de uma análise da totalidade corporal, vinculado à última -, consoante Foucault elas pressupōem, sem o dizer, o novo estatuto assumido pelo discurso médico.

Este estatuto tampouco deve ser entendido sob a égide da expressão, da tradução ou do reflexo: o que muda com as novas condições de existência e funcionamento do discurso médico não são "consciências" nem "conceitos", mas práticas. Quando, digamos, se passa a falar de "focos lesionais" em lugar de "espécies mórbidas", isso não se dá porque o novo estatuto altera diretamente o objeto médico, e sim porque ele oferece à medicina "quer seja uma população vigiada e repertoriada, quer seja uma evolução patológica total no indivíduo [...], quer seja um espaço anatômico autopsiado" (Foucault, 1972: 75-76).

\section{UMA MULTIPLICIDADE DE QUESTÓES}

O título deste ensaio atribui resposta a "muitas questões" ao parágrafo que vimos examinando. A primeira questão já foi evidenciada: quais as relações entre a prática política e um discurso científico? Antes de retomá-la e desdobrá-la em outras, cumpre apresentar a urgência que nos mobiliza, a qual merece (e mesmo exige) ser pensada. 
Ao final de 2007, chegou ao conhecimento público a notícia intitulada "Grupo vai analisar aspectos genético, psicológico, social e cerebral de adolescentes", publicada na Folha de São Paulo (FSP) e abaixo parcialmente transcrita ${ }^{7}$.

Cientistas da PUC-RS [...] e da UFRGS [...] querem saber se o que determina o comportamento de um menor infrator é sua história de vida e se há algo físico no cérebro levando-o à agressividade. "Algo que sempre foi negligenciado foi o entendimento da violência como aspecto de saúde pública", diz Jaderson da Costa, neurocientista da PUC-RS [...]. A idéia é entender quais pontos são mais relevantes $[. .$.$] na hora de determinar como se produz uma mente crimi-$ nosa. [...] Serão examinados dois grupos: um de internos da Fase ${ }^{8}$ e outro de meninos sem passado de crime [...]. O projeto vai olhar para questôes sociais, mas o foco é mesmo o fundo biológico [...]. "Estamos nos baseando em trabalhos que já existem ${ }^{9}$ mostrando que [...] se uma criança é maltratada entre o $8^{\circ}$ e o $18^{\circ}$ mês ela adquire comportamento alterado na idade adulta", diz um dos mentores do projeto, o secretário de Estado da Saúde do RGS, Osmar Terra, aluno de mestrado de Costa. "Decidi no ano passado retomar a neurociência como opção de vida; minha opção não é fazer política até morrer”, diz. [...] Para os cientistas, um ambiente de desenvolvimento inadequado pode mesmo "fabricar" um psicopata [...]. O papel do mapeamento cerebral por ressonância magnética [...] é tentar entender a manifestação física de problemas como esse. [...] O DNA dos meninos também será analisado. O projeto [...] ainda está sendo analisado por um comitê de ética da PUC-RS, e os cientistas se dizem confiantes de que a aprovação sairá para início dos trabalhos em março de 2008. O custo [...], avaliado [...] em cerca de R $\$ 120$ mil, será coberto com doações da siderúrgica Gerdau para a pesquisa, afirma o secretário da Saúde.

Uma cena freqüente nas reunióes universitárias em que se trouxe o tema à baila foi a desqualificação da reportagem. Muito se recomendou a leitura do projeto - uma "imprensa pouco confiável" justificaria essa cautela. Foi também comum o fato de professores receberem, por e-mail, artigos editados por periódicos "de renome", que atestariam a seriedade da investigação ${ }^{10}$.

As afirmações da matéria, contudo, implicaram respostas menos academicistas. Professores, pesquisadores, entidades e movimentos sociais começaram a enviar mensagens eletrônicas a suas listas, indagando "o que fazer?”. O processo se acentuou após a leitura de duas outras notícias, também publicadas na FSP ${ }^{11}$, das quais reproduzimos trechos a seguir. 
Para grupo de pesquisa, índole violenta é uma doença mental

"Esse conhecimento tem de ser referenciado para políticas públicas", diz o secretário estadual da Saúde Osmar Terra [...]. "Estamos 'medicalizando' questôes sociais", diz Renato Flores. [...] "Acho que isso vai servir para fazer a prevenção", diz Jaderson da Costa. [...] "Nessa questão o livre arbítrio está indo pelo ralo" [...], diz Flores, que defende uma reavaliação da tradição jurídica sobre punição. [...] "Acho que quando o psicopata comete um crime grave ele não pode sair da prisão", diz Terra. Alguns agressores, porém, podem ser "tratáveis". Para isso, Flores defende o controle externo. "O que funciona é dizer ao paciente: 'Vou ficar no teu pé, tu tens que vir na consulta [do psicólogo], e se tu aprontar nós vamos estar te olhando”".

Problema não é no DNA, mas os genes influenciam, diz cientista

É errado enfocar a análise do comportamento violento na genética. Essa é a opinião do geneticista Renato Zamora Flores, da UFRGS [...]. "Nenhum polimorfismo age sozinho nem influencia comportamento violento sem um efeito ambiental por trás" [...]. Um dos genes-alvo [...] é o que codifica a enzima monoamina-oxidase (MAO), apontado por um estudo [...] do psicólogo Avshalom Caspi. O trabalho mostrou que meninos maltratados estavam sob maior risco de se tornar adultos violentos se fossem portadores de uma certa variedade do gene da MAO.

Ao longo da troca de mensagens, alguém esboçou uma Nota de Repúdio, paulatinamente modificada e ampliada pelos demais até resultar na seguinte versão.

Estudos sobre a "base biológica para a violência em menores infratores": novas máscaras para velhas práticas de extermínio e exclusão

É com tristeza e preocupação que recebemos a notícia de que Universidades de grande visibilidade na vida acadêmica brasileira estão destinando recursos e investimentos para velhas práticas de exclusão e de extermínio. A notícia de que a PUC-RS e a UFRGS vão realizar estudos e mapeamentos de ressonância magnética no cérebro de 50 adolescentes infratores para analisar aspectos neurológicos que seriam causadores de suas práticas de infração nos remete às mais arcaicas e retrógradas práticas eugenistas do início do século XX. Privilegiar aspectos biológicos para a compreensão dos atos infracionais dos adolescentes em detrimento de análises que levem em conta os jogos de podersaber que se constituem na complexa realidade brasileira e que provocam tais fenômenos é ratificar sob o agasalho da ciência que os adolescentes são o 
princípio, o meio e o fim do problema, identificando-os seja como "inimigo interno" seja como "perigo biológico", desconhecendo toda a luta pelos direitos das crianças e dos adolescentes, que culminou na aprovação da legislação em vigor - o Estatuto da Criança e do Adolescente. Pensar o fenômeno da violência no Brasil de hoje é construir um pensamento complexo, que leve em consideração as Redes que são cada vez mais fragmentadas, o medo do futuro cada vez mais concreto e a ausência de instituiçôes que de fato construam alianças com as populações mais excluídas. É falar da corrupção que produz morte e isolamento e da precariedade das políticas públicas, sejam elas as políticas sociais básicas como educação e saúde, sejam elas as medidas sócio-educativas ou de proteção especial. Enquanto a Universidade se colocar como um ente externo que apenas fragmenta, analisa e estuda este real, sem entender e analisar suas reais implicações na produção desta realidade, a porta continuará aberta para a disseminação de práticas excludentes, de realidades genocidas, de estudos que mantêm as coisas como estão. Violência não é apenas o cometimento do ato infracional do adolescente, mas também todas aquelas ações que disseminam perspectivas e práticas que reforçam a exclusão, o medo, a morte. Triste universidade esta que ainda se mobiliza para este tipo de estudo, esquecendo-se que a Proteção Integral que embasa o ECA compreende a criança e o adolescente não apenas como "sujeito de direitos" mas também como "pessoa em desenvolvimento" - o que por si já é suficiente para não engessar o adolescente em uma identidade qualquer, seja ela de "violento" ou "incorrigível". A universidade brasileira pode desejar um outro futuro: o de estar à altura de nossas crianças e adolescentes ${ }^{12}$.

A nota ganhou divulgação através das páginas de entidades e movimentos sociais ligados aos direitos da infância. Não obstante tenha angariado muitas adesões, os "repúdios ao repúdio" foram proporcionalmente intensos. O CIEPSI (Centro Internacional de Estudos e Pesquisas sobre a Infância) - um dos primeiros endereços a exibir o texto e a lista de signatários - recebeu inúmeros e-mails que discordavam veementemente das objeçōes levantadas. Eis pequena amostra.

Uma das razōes por que saí do Brasil há 11 anos [...] é a visão curta e rasa dos acadêmicos no Brasil [...]. Sabemos que a educação e a pesquisa são áreas vitais para o desenvolvimento e sobrevivência de uma nação. Não aceitar isso é viver na contramão e no atraso...

Li a nota de repúdio na Folha de hoje... Só me resta saber onde vocês vão armar a fogueira inquisitorial. [...] Não é um feudalismo acadêmico... é um comportamento jurássico. 
Foi com espanto que li a reportagem da Folha [...]. Enquanto a eugenia é reducionista, o estudo [...] propõe ampliar o conhecimento dos diversos fatores que podem levar um jovem a cometer um homicídio. Os que se colocam contra o trabalho devem temer que a ressonância nuclear magnética ou o exame do material genético encontre marcadores que [...] servirão como estigmas [...]. Tal idéia está mais próxima de filmes de ficção científica ou histórias de bruxas medievais do que da ciência séria. [...] Querer proibir o progresso científico [...] foi prática comum durante a idade média, sendo muito utilizada pelos tribunais da inquisição [...]. É apavorante ver tantas pessoas e entidades comportando-se como delegados do stalinismo.

Os dois últimos e-mails mencionam a Folha de São Paulo. Não mais se trata, porém, das matérias de 26/11/2007. Em 21/01/2008, sob a chamada "Nota de repúdio liga projeto à eugenia e a práticas de exclusão e de extermínio”, o jornal transcreveu o texto da nota e publicou nova reportagem, da qual citamos partes.

Psicólogos tentam impedir pesquisa com homicidas ${ }^{13}$

Um grupo de mais de cem pessoas, que inclui psicólogos, advogados, antropólogos e educadores, quer tentar impedir a realização de um projeto de pesquisa que pretende mapear o cérebro de 50 adolescentes homicidas [...]. A reação [...] cresceu a partir de dezembro passado, quando um abaixo-assinado acompanhado de uma nota de repúdio de autoria coletiva começou a circular. [...] Dois dos líderes do projeto [...] são o neurocientista Jaderson da Costa [...] e o geneticista Renato Zamora Flores [...]. Um aluno de mestrado no grupo é o secretário da Saúde do Estado, Osmar Terra [...]. O projeto [...] ainda não foi protocolado no comitê de ética da PUC-RS, [...] mas alguns signatários [...] já estão organizando uma reação. "A gente pretende evitar que ele se realize", diz Ana Luiza Castro, psicóloga do Juizado da Infância e Juventude de Porto Alegre. "Entendemos que ele fere o Estatuto da Criança e do Adolescente e fere os direitos humanos porque [...] liga a violência a um determinado grupo social”.

Na mesma edição da FSP, Renato Zamora Flores, citado como (mais) um dos líderes do projeto, é convidado a escrever sobre "o outro lado" - sendo "o lado", evidentemente, o repúdio à pesquisa. Transcrevemos parte do escrito.

Feudalismo acadêmico nas ciências sociais

Talvez o maior desafio da interdisciplinaridade seja a necessidade de entendermos como funcionam outras áreas do conhecimento [...]. O problema parece ser especialmente grave entre cientistas e psicólogos sociais que, de modo geral, 
desconhecem o conjunto de áreas do conhecimento denominadas de neurociências [...]. No Brasil, devido a um indiscutível feudalismo científico, a maioria dos cursos de ciências sociais e de psicologia simplesmente ignora o que ocorre em outras áreas do conhecimento e forma profissionais que [...] não conseguem entender o que ocorre na seara alheia. Assim, quando propusemos um estudo sobre adolescentes violentos, descrito com propriedade em matéria da Folha [...], fomos surpreendidos com uma estapafúrdia nota de repúdio que [...] qualificava o empreendimento [...] de eugênico e vinculado a práticas de extermínio. Os críticos parecem acreditar que fenômenos mentais e sociais ocorrem independentemente dos cérebros dos indivíduos. Para eles, estudos biológicos do comportamento são irrelevantes pois os efeitos da cultura e do ambiente social afetam a mente, que deve estar em algum lugar que não o cérebro, talvez em uma estrutura etérea como a alma. [...] Como a nota de repúdio explica, por exemplo, o vínculo com o conceito de "eugenia"? Esse é um termo criado por Francis Galton (1822-1911), que o definiu como "o estudo dos agentes sob o controle social que podem melhorar ou empobrecer as qualidades raciais das futuras gerações, seja física ou mentalmente". Tal prática foi utilizada por norte-americanos e alemães na primeira metade do século 20, sem qualquer resultado relevante. [...] Apenas os que desconhecem esse aspecto da história vinculariam o estudo proposto a uma prática tão ineficiente e cruel. [...] Por que fazer uso da defesa dos direitos humanos e das crianças como escudo para fundamentar a pregação de uma única forma de fazer pesquisa?

Ao divulgar a nota e a réplica de Flores, a FSP aparentava - a despeito do tom sensacionalista e pouco preciso das chamadas ${ }^{14}$ - ter a intenção de promover o debate. No entanto, em 22/01/2008, um de seus editoriais se posiciona contra o repúdio. Eis parte do texto.

\section{Razão e preconceito}

Enviesada e precipitada: é o mínimo que se deve dizer da nota de repúdio de uma centena de psicólogos, advogados, antropólogos e educadores contra estudo biológico sobre comportamento violento de 50 jovens infratores [...]. O projeto nem foi submetido a um comitê de ética [...], mas os signatários já lhe atribuem "velhas práticas de exclusão e de extermínio" e "retrógradas práticas eugenistas". [...] O protocolo da pesquisa prevê obtenção de consentimento dos jovens estudados, de familiares e até do Poder Judiciário. Nada garante que identifique correlaçôes significativas. Excluí-las de antemão, contudo, só ocorre a quem nega a priori que eventos cerebrais sejam relevantes para explicar o 
comportamento. [...] No século 19 e no início do 20, de fato, a suposição atabalhoada de uma relação causal entre características físicas (inclusive "raça") e capacidade mental, sem base real, produziu monstruosidades. Essa pseudociência foi demolida com argumentos teóricos e resultados empíricos [...]. Nas "Regras para a direção do espírito", Descartes alertava já em 1628 que prevenção e precipitação são as grandes fontes do erro.

Exposta a polêmica, urge debatê-la, voltando "para fora” os óculos oferecidos pelo parágrafo foucaultiano por nós privilegiado.

\section{Política E Discursos CIENTÍfICOS}

Conforme antecipamos, assim responde Foucault à indagação acerca das relações entre política e ciências: elas são, por um lado, diretas - não passam em primeiro lugar pela consciência dos sujeitos nem por seu pensamento, mas engendram, de um só golpe, regras de existência e funcionamento do discurso científico -; por outro lado, entretanto, são indiretas - o discurso científico não é expressão imediata (mental, ideológica ou conceitual) de uma dada situação econômica, social etc. A esse respeito, examinemos um primeiro aspecto do problema que nos inquieta.

Por mais que se as ignore em detalhe, dificilmente se poderia negar que há, no Brasil, uma multiplicidade de iniciativas dirigidas a crianças e adolescentes. Independentemente de como viéssemos a avaliá-las caso as conhecêssemos bem, muitas delas batalham por visibilidade e alianças, sem o conseguir. Não é ocorrência sem importância, portanto, que a "pesquisa dos cérebros" - alcunha que passaremos, por comodidade, a utilizar - nos chegue através da grande imprensa. Pois se esta raramente concede espaço ao agir minoritário ${ }^{15}$, está quase sempre disponível para exibir tudo aquilo que, sob a égide das ciências, se propóe a corrigir nossas supostas mazelas sociais.

Quanto a isso, a primeira reportagem é exemplar: cientistas de duas grandes universidades de uma grande cidade brasileira, dentre os quais há doutores, mestres e mestrandos - um deles, ademais, secretário de saúde do Estado -, merecem que se lhes divulgue amplamente as iniciativas (o que não seria tão fácil no caso de agentes e movimentos não dotados de tais "certificações"). Alegar que o debate deveria ser postergado, e que nosso ${ }^{16}$ tempo seria mais bem empregado na leitura do projeto, provavelmente "distorcido", é esquecer-se do estatuto atual das (neuro)ciências: se estão na mídia, é porque suas condições de existência e funcionamento são reguladoras, capilares, performativas. Sob tal perspectiva, a Nota de 
Repúdio não é precipitada: vem no tempo oportuno, tempo das relações diretas entre prática política e discursos científicos - como no tempo oportuno viera a publicação na mídia, pois não se pesquisa sem prestígio e propagação (talvez invertendo os dois últimos termos...). Vale também ressaltar que não houve críticas tão inflamadas quanto as feitas à nota, por sua alegada precipitação, aos responsáveis pela "pesquisa dos cérebros", por: tornarem público o que sequer fora aprovado em suas universidades; anunciarem futuros (e vultosos) financiamentos privados; proclamarem-se autorizados a "mapear cérebros" antes do consentimento ${ }^{17}$ dos "mapeáveis"; proporem-se a modificar políticas públicas com base em futuros (desconhecidos, mas antecipados) resultados etc. Porém tudo isso, que pareceu tão comum, ou mesmo desculpável, nada tem de natural: é uma prática não necessariamente desejável ou indiscutível, nem apenas ocasionalmente divulgada através da grande imprensa. Esta veicula a "pesquisa dos cérebros", e a veicula "com propriedade", aliás, segundo afirmou Flores -, porque isso é parte do estatuto dos discursos científicos na contemporaneidade.

Mas se a nota vem no tempo oportuno e, decerto, também parcialmente apoiada em tal estatuto - não fossem muitos de seus signatários pesquisadores universitários, teríamos chegado a conhecê-la ${ }^{318}$-, será repudiável pelo conteúdo? É a partir daqui que damos início ao desdobramento do parágrafo de Foucault em "muitas questôes".

Segunda questão: podemos extrair da prática política critérios de julgamento de cientificidade? Consoante Foucault (1972), "a prática política não reduz a nada a consistência do campo discursivo no qual ela opera” (Foucault, 1972: 76). Em face dessa autonomia ao menos relativa, estaríamos impedidos de nos pronunciar sobre as ciências? Não se trata disso. Ainda de acordo com Foucault, embora a prática política não seja o tribunal universal da razão, pode-se, em nome dela, "colocar em questão o modo de existência e de funcionamento de uma ciência” (Foucault, 1972: 77) - interrogar, em suma, aquilo que está diretamente relacionado com a prática política.

Voltemos à nota. Seu conteúdo se atém a essa relação direta? Nem sempre. Arvora-se ela em tribunal último? Dificilmente se poderia afirmá-lo. Senão vejamos.

Talvez o trecho em que a relação entre política e cientificidade esteja manifestamente em pauta seja o seguinte:

Privilegiar aspectos biológicos para a compreensão dos atos infracionais dos adolescentes em detrimento de análises que levem em conta os jogos de podersaber que se constituem na complexa realidade brasileira e que provocam tais fenômenos é ratificar sob o agasalho da ciência que os adolescentes são o princí- 
pio, o meio e o fim do problema, identificando-os seja como "inimigo interno" seja como "perigo biológico", desconhecendo toda a luta pelos direitos das crianças $e$ dos adolescentes, que culminou na aprovação da legislação em vigor - o Estatuto da Criança e do Adolescente. Pensar o fenômeno da violência no Brasil de hoje é construir um pensamento complexo... (grifos nossos).

Dizer, no calor da hora, que "os jogos de poder-saber" provocam "os atos infracionais dos adolescentes" - é o que se depreende do texto - e que a pesquisa dos cérebros, ao contrário, visa a reduzi-los a aspectos biológicos é aderir às hipóteses abandonadas por Foucault, no caso assim sintetizáveis: os setores progressistas - aqueles que lutaram pelo ECA, digamos - são dotados de percepções e idéias complexas, levando em conta, no modo de perceber e conceituar as infrações, os fatores sociais, ao passo que os setores reacionários, de forma simplista e redutora, vêem e conceituam os mesmos fenômenos como decorrentes de uma má herança e/ou um mau ambiente.

Os repudiadores do repúdio apropriaram-se prazerosamente desse aspecto, invertendo a balança do tribunal: segundo eles, os signatários da nota seriam inquisidores, religiosos tacanhos (a discussão sobre as pesquisas com células-tronco foi mais do que uma "entrelinha"), stalinistas, ou quaisquer outros qualificativos que servissem para vincular a crítica a um reflexo direto de (objetáveis) posições políticas. Preconceito, feudalismo acadêmico, atraso, jurassismo, idealismo (mente etérea, uma "alma”) etc. foram expressões manejadas à larga.

Quanto ao conteúdo, portanto, a nota mostrou-se equívoca (quiçá equivocada). Pois os "jogos de poder-saber" evidentemente não produzem os atos infracionais dos adolescentes, embora sem dúvida configurem - e diretamente - o estatuto de certos discursos para falar sobre os mesmos (que, vale frisar, não são sempre os mesmos atos, a depender de quem é considerado competente para deles falar).

A despeito dessa ressalva, em momento algum a Nota de Repúdio lançou mão de argumentos epistemológicos. Em nenhum ponto do texto, ademais, falou-se em impedir a realização do projeto. A nota não vetava ${ }^{19}$. A expressão "triste universidade essa", associada ao pretenso veto, constituía, de forma nítida, um diagnóstico da ausência de reflexão acerca dos nexos (diretos) entre a prática política e as ciências; lamentava que na academia ainda se difundam (e sejam placidamente acatados) discursos que se apóiam em evidências apodíticas (Descartes não emergiu à-toa no Editorial da FSP), em auto-divinizantes neutralidades, em inodoras epistemofilias ${ }^{20}$.

Terceira questão: as relações entre uma prática política e um campo discursivo estão articuladas a relações com outros campos discursivos? Ao ver de Foucault, é 
evidente que sim. Aqui, entretanto, uma vez mais cumpre abandonar noções como transferência e metaforização de conceitos. Porque se importação entre campos discursivos ocorre - como é perceptível, por exemplo, em noçôes como organismo social, função social, evolução social ou patologia social -, isso se dá "em razão do estatuto dado ao discurso médico pela prática política” (Foucault, 1972: 77), e não por intermédio de uma grande alma cognitiva cujos elementos se comunicariam sem barreiras.

Quanto a essa questão, o tema da eugenia vem à cena. Estaria a "pesquisa dos cérebros" relacionada ao discurso eugenista? O próprio Flores nos ajuda a responder, ao afirmar que esse "estudo dos agentes sob o controle social que podem melhorar ou empobrecer as qualidades raciais das futuras gerações" foi utilizado por "norte-americanos e alemães na primeira metade do século 20, sem qualquer resultado relevante", acrescentando que "apenas os que desconhecem esse aspecto da história vinculariam o estudo proposto a uma prática tão ineficiente e cruel”. Esquece-se ele de dizer, contudo, que a relevância da eugenia não está em seus resultados - quais seriam, por sinal, esses resultados relevantes? -, mas no problema que ela é "eficiente" em formular - problema que pressupõe poder dispor, manejar, modificar, isto é, gestionar, pôr sob controle, certos agentes com vistas ao aprimoramento de uma sociedade.

A alegada (por Flores) ineficiência da eugenia só pôde ser "demonstrada" porque ela foi primeiramente ${ }^{21}$ instituída, praticada, difundida; porque dispôs de corpos e populações para ser ensaiada, financiada, propagandeada... Triste universidade essa, reiteramos ${ }^{22}$, que pensa que suas pesquisas se fazem num vácuo político e que somente seus ilibados resultados (obtidos sem estatuto prévio?) serão aplicados, a posteriori, a "relevantes" políticas públicas. Muitos dos repúdios à nota estão permeados da eficiência do discurso eugênico, forjada por um modo de existência, inserção e funcionamento que lhe facultou articular-se a inúmeros campos discursivos - a ponto de engendrar modos de pensar a vida, subjetiva e social, como organismo e espécie avaliáveis como saudáveis ou doentes pelos discursos e práticas científicos, cujos agentes deveriam defender dos patológicos, errôneos, elimináveis, nossa (orgânica) sociedade, "tratando-a".

Quando se tenta ridicularizar a Nota de Repúdio, atribuindo-lhe anacronismo e desorientação - o século XIX e a primeira metade do século XX foram muito citados, bem como os americanos e alemães -, ignora-se ativamente o estatuto associado à "pesquisa dos cérebros", qual seja: dispor aprioristicamente da vida e dos corpos daqueles que serão seus "sujeitos neuronais", sob o suposto de que a articulação entre o discurso neurocientífico e o discurso das ações (e controles) sociais constitua irrecusável obviedade. A nota diz que estas presumidas novas 
práticas constituem velhas práticas, pois muitas durações são incrivelmente longas, além de geopoliticamente dispersas. Mas insiste sobretudo em reafirmar que são práticas, exercícios, e não a carreira gloriosa e irrecusável da Razão-Civilização Ocidental.

Quarta questão: quando nos eximimos de analisar as condições de existência e funcionamento dos discursos científicos, o que resta à prática política? Nas palavras de Foucault, uma escolha perigosa:

ou colocar, de maneira que se pode muito bem chamar [...] de "tecnocrática", a validade e eficacidade de um discurso científico, quaisquer que sejam as condiçôes reais de seu exercício e o conjunto das práticas sobre as quais ele se articula [...]; ou intervir diretamente no campo discursivo, como se ele não tivesse consistência própria, fazer dele a matéria bruta de uma inquisição psicológica (julgando um pelo outro o que é dito e aquele que diz), ou praticar a valorização simbólica das noçôes (discernindo numa ciência os conceitos que são "reacionários" e os que são "progressistas") (Foucault, 1972: 78).

Nenhum dos que repudiam a nota se propõe a analisar o estatuto contemporâneo dos discursos biológico e neurocientífico. Já a própria nota, embora esboce tal análise - em uma alusão desajeitada aos "jogos de poder-saber" -, não chega a dela fazer o cerne da problematização. Nessas circunstâncias, tomam a frente funestas alternativas.

De tecnocracia estão repletas as declarações dos líderes da pesquisa dos cérebros, com o beneplácito de missivistas eletrônicos e editorialistas. Afinal, com que direito psicólogos e cientistas sociais, que nada sabem sobre campos alheios à própria seara, ousam criticar uma investigação a ser realizada por especialistas em genética, biologia, neurociências? Com que fundamentos, já que somente os científicos merecem lugar na arena, se atrevem a rejeitar que questôes sociais sejam medicalizadas, que se faça a prevenção (cientificamente garantida) da violência e que se revise, endurecendo-a para "os psicopatas", a tradição jurídica sobre a punição? Como podem levantar dúvidas sobre os benefícios de uma investigação assentada naquilo que retrata o "estado da arte" seja quanto à identificação do momento em que se adquirem regras morais, seja no que tange às conseqüências da presença, no organismo, do gene da $\mathrm{MAO}^{23}$ ? A que validade aspiram, em face de autoridades como Antonio Damásio e Avshalom Caspi, os protestos de pessoas de "visão curta e rasa", partidárias do "atraso nacional", crédulas em histórias de "ficção científica" e "bruxaria", proselitistas, pregadores escudados na defesa dos Direitos Humanos e das crianças? 
Estendemo-nos na revisão da opção tecnocrática e, meio ao acaso do discurso, mostramos que não está desconectada de sua alternativa, a inquisição psicológica e/ou simbólica - pois aquele que diz algo diverso da tecnocracia só merece o opróbrio (pessoal, cognitivo, político, conceitual... vital?).

Terá a Nota de Repúdio recaído no mesmo binarismo (tecnocracia/inquisição), sendo alvo, como efeito de retorno, das regras que tentara instaurar? Dificilmente se poderia dizer que sim. Conquanto o texto não analise com a desejável agudeza o estatuto contemporâneo dos discursos biológico e neurocientífico, nele não se faz presente a opção tecnocrática e, se inquisição existe, não é psicológica a nota fala de práticas ${ }^{24}$, e não de pessoas julgadas/categorizadas pelo que dizem. Haveria, então, inquisição conceitual, delimitando conceitos "reacionários" e "progressistas"? Com exceção de uma breve (e vaga) referência ao "pensamento complexo" - dirigida contra a nota nas réplicas ${ }^{25}$-, o repúdio à "pesquisa dos cérebros" não efetua partição valorativa de noções, por mais que muito se tenha insistido nisso - alegando, por exemplo, que defenderia "a alma" contra "o cérebro", "o social" contra "o biológico", o monodisciplinar fechado contra o multi-inter-polidisciplinar aberto etc.

Finalmente, quinta questão: haveria possibilidade de uma política efetivamente progressista no campo da análise dos discursos científicos? Foucault nos oferece a seguinte hipótese:

Uma política progressista não se encontra por respeito ao discurso científico numa posição de "demanda perpétua" ou de "crítica soberana", mas ela deve conhecer a maneira pela qual os diversos discursos científicos, em sua positividade (isto é, enquanto práticas ligadas a certas condiçôes, submetidas a certas regras, e suscetíveis de certas transformaçôes) se encontram colocadas num sistema de correlações com outras práticas (Foucault, 1972: 79).

Não é coisa diversa o que defende a Nota de Repúdio. Discurso que se afirma como exercício político - por acaso seria, hoje, um atentado ao pudor acadêmico fazê-lo? -, ela recusa a subserviência a qualquer prática, científica inclusive, que se arvore em regra universal e incondicionada. Sem a pretensão de intervir, mediante algum juízo epistemológico final, no campo discursivo da "pesquisa dos cérebros", a nota se mantém em meio às regras que conformam qualquer prática sócio-histórica (a própria nota não escapa à regulação); porém, justamente por isso, autoriza-se a anunciar os riscos que corremos, todos (cientistas ou não), quando desconsideramos as correlações do discurso científico com práticas outras - que, na situação em apreço, são as de culpabilização, 
identificação de "inimigos internos" e/ou "perigos biológicos", cisão sapiente entre (bons) cidadãos e rebotalho social.

\section{CONSIDERAÇÕES FINAIS}

Quando, ao longo deste ensaio, insistimos em diferenciar relações diretas e relações indiretas entre política e discursos científicos - aspecto presente nas seis questões-respostas abordadas -, não pretendemos defender uma política soberana (porque "humana" e defensora do "humano"); tampouco visamos fixar idéias e conceitos justos porque reflexos ou transposiçōes dessa mesma política (o que deles faria idéias e conceitos "humanos" ou defensores do "humano").

Encaminhamo-nos, sim, a uma política que diríamos crítica: aquela que se propõe a refletir sobre (e a intervir nas) condições de existência, inserção e funcionamento dos discursos científicos, com as quais a prática política mantém, conforme julgamos ter explicitado, relações muito diretas.

$\mathrm{Na}$ conflitiva ligada à "pesquisa dos cérebros", a defesa pretendida não é tanto, pois, a dos direitos do "homem" - o que seria esse "curioso objeto... o homem" (Foucault, 1972: 79), fora do que dele fazem discursos (hoje predominantemente científicos) e práticas correlatas? -, mas a dos direitos dos governados melhor dizendo, dos direitos de não sermos governados, se não em absoluto, ao menos de não o sermos por princípios, agentes e instâncias que nos pretendem conduzir, sem contestação possível, mediante o poder da verdade (científica, biológica... neurocientífica, cerebral?).

O presente ensaio constitui um exercício de reflexão no âmbito dessa política crítica, dessa defesa dos direitos dos governados. Bem antes, em 6/02/2008, Suyanna Barker e Esther Arantes publicaram na FSP o texto "Porque assinamos a Nota de Repúdio". Finalizamos nossa intervenção com parte dele, pois, em diferentes condições de existência (espaço, recepção, efeitos), não dizemos coisas diferentes.

Nós, da Comissão Regional de Direitos Humanos do CRP-RJ, contribuímos com a redação (coletiva) da nota e a assinamos. A nota circulou acompanhada de um texto esclarecendo que não se tratava de um repúdio às universidades nem a seus professores, funcionários e alunos. Tampouco contra a pesquisa, em geral, sendo seu objetivo suscitar o debate [...]. Acaso não era previsível que uma pesquisa que se dispõe a mapear o cérebro de supostos "adolescentes homicidas" para verificar como se produz uma suposta "mente criminosa" suscitaria indagações de diversas ordens? Não era igualmente previsível que a afirma- 
ção abaixo, embora sob a capa de pretensa unanimidade sobre o fazer do psicólogo, motivasse protesto por parte destes profissionais? Vejamos o trecho: "O que funciona é dizer ao paciente: 'Vou ficar no teu pé, tu tens que vir na consulta [do psicólogo] e, se tu aprontar, nós vamos estar te olhando". [...]. A nota [...] repudia, não veta - a decisão sobre a pertinência ética de pesquisas, por sinal, ainda é assunto de comitês, e não de um debate amplo e público como o que procuramos iniciar. Mas, certamente, lamentamos a iniciativa deste projeto, por reforçar [...] as discriminações e estereótipos que já marcam certos sujeitos, como fica claro quando se os chama [...] de "homicidas", deixando subentendido tratar-se de "cérebros de homicidas". Todos sabemos que os adolescentes que se encontram em unidades de privação de liberdade fazem parte das camadas mais pobres da sociedade [...]. Nesse sentido, cumpre lembrar que [...] qualquer pergunta - e pesquisas formulam perguntas - pressupõe uma afirmação. E a afirmação da pesquisa em pauta [...] admite que existam cérebros "criminosos" em oposição a "não-criminosos", ignorando a rede de poderes que se articula com tal suposição (mesmo que pretenda investigá-la cientificamente). A luta na Constituinte de 1987 [...] foi para que nunca mais houvesse, no Brasil, duas infâncias: a "criança e o adolescente" e o "menor". Assim, quando falamos de nossa "tristeza" quanto ao projeto em pauta, falamos da tristeza de perceber que mesmo na universidade é possível fazer pesquisa sem a devida reflexão sobre as condições e efeitos políticos da mesma, sobre as implicações de seus temas e métodos, sobre o papel de cada ator e acadêmico na construção do que, com demasiada facilidade, se diz ser "o real". Pois [...] este não é algo a ser constatado ou desvelado, mas uma construção cotidiana forjada em meio a lutas e conflitos. E isso inclusive quando se trata de tema aparentemente tão concreto, factual, objetivo, científico e da exclusiva competência de especialistas como um "cérebro" submetido a "mapeamento". Assinamos a nota, portanto, não como preconceituosos censores contrários a uma inquestionável razão, mas enquanto pessoas, entidades e movimentos que não pretendem se calar diante de uma certa racionalidade que nos quer situar, a todos, como "menores" em face de sua pretensa validade indiscutível.

\section{REFERÊNCIAS BIBLIOGRÁFICAS}

Foucault, M. (1969). O que é um autor?. Lisboa: Vega, 1992. (1972). Resposta a uma questão. Tempo Brasileiro, 28, 57-81.

Foucault, M. \& Deleuze, G. (1979). Os intelectuais e o poder. Em Foucault, M. Microfísica do poder (pp. 69-78). Rio de Janeiro: Graal. 


\section{Notas}

1 Expressão contida em reportagens que divulgaram a pesquisa, como veremos.

2 No original: "Réponse à une question", Esprit, mai 1968, pp. 850-874. Utilizamos Foucault, 1972.

3 Juntamente com "Réponse au Cercle d'Épistémologie". Cahiers pour l'analyse, 9, été 1968, pp. 9-40.

4 A continuidade afirmada por Foucault ainda nos soa fecunda: o estatuto contemporâneo dos discursos biológico e neurocientífico se vê iluminado pelo exemplo do discurso clínico na medicina.

5 É difícil ignorar, nessa análise, o assinalamento de formas de exercício de poder que, mais tarde, serão problematizadas como biopolítica.

6 FSP, 26/11/2007, assinada por Rafael Garcia.

7 O espaço disponível não permite transcrição integral. Fizemos o possível para que as supressões não produzissem distorçôes.

8 Fundação de Atendimento Socio-Educativo, quase sempre referida como "antiga Febem gaúcha”.

9 Segundo a reportagem, os pesquisadores se apóiam nos trabalhos do neurocientista Antonio Damásio.

${ }^{10}$ No Departamento de Psicologia Social da UERJ, recebemos "A biologia na violência", de Renato Zamora Flores (Ciência e Saúde Coletiva, 2002, 7(1)); "Fatores etiológicos da agressão física: uma revisão teórica”, de Christian Haag Kristensen e cols. (Estudos de Psicologia, 2003, 8(1)) e "Role of genotype in the cycle of violence in maltreated children", de Avshalom Caspi e cols. (Science, vol. 297, 2/08/2002).

${ }^{11}$ As matérias foram publicadas em 26/11/2007, atribuídas ao "enviado a Porto Alegre".

${ }^{12}$ Em 21/01/2008, data da publicação, a nota contava com 108 signatários. Na última consulta à página do Conselho Regional de Psicologia-RJ, em 22/08/2008, o número chegara a 148.

${ }^{13}$ A reportagem é de autoria de Rafael Garcia, que assinara a matéria principal em 26/11/2007.

${ }^{14}$ A chamada "Psicólogos tentam impedir pesquisa com homicidas" leva a crer que o repúdio seria exclusivo dos psicólogos, o que não se confirma. Já "Nota de repúdio liga projeto à eugenia e a 'práticas de exclusão e de extermínio"” supervaloriza o tema da eugenia contido no texto da nota.

${ }^{15}$ Usamos o termo no sentido deleuze-guattariano: processo que não está capturado em formas instituídas, do tipo estatal-molar.

${ }^{16}$ O pronome "nosso" não é artifício retórico. Sou signatária da Nota de Repúdio, como professora do Curso de Especialização em Psicologia Jurídica da UERJ. No momento oportuno, é preciso assumir um lado. Somente depois começa o tempo de debater a constituição (histórico-política) dos dois lados. 
${ }^{17}$ Não vemos o "termo de consentimento livre e esclarecido" como panacéia. Porém nem mesmo esse parco instrumento - em relação ao qual, tratando-se de adolescentes internados na Fase, "liberdade" e "esclarecimento" soam paradoxais - foi mencionado nas primeiras reportagens. Sua inclusão só se deu após as críticas dirigidas ao projeto.

${ }^{18}$ Conferir as várias menções a "psicólogos, antropólogos, cientistas sociais, educadores etc". Praticamente não se alude a entidades e movimentos sociais (falta-lhes estatuto para se pronunciar?).

19 A única iniciativa de veto foi tomada por Ana Luiza Castro, para quem a pesquisa fere o ECA e os Direitos Humanos ao ligar a violência a um grupo social determinado - argumento que remete apenas à dimensão política.

${ }^{20}$ Quanto a este ponto, é quase cômico ver o secretário da Saúde do RGS dizer, ao liderar uma investigação a ser financiada pela Siderúrgica Gerdau, que não pretende "fazer política a vida toda”...

${ }^{21} \mathrm{O}$ termo se refere a uma primazia lógica, não necessariamente cronológica.

${ }^{22}$ A expressão é parcialmente retórica, pois a Universidade é feita de diferenças, somente diferenças. Na polêmica em exame, entretanto, mostrou-se dominantemente silenciosa, quando não condenatória das objeções à "pesquisa dos cérebros".

${ }^{23}$ Rigor e humor não são incompatíveis: a sonoridade da sigla MAO será mera coincidência?

${ }^{24}$ Conferir na Nota de Repúdio: práticas de extermínio e exclusão, de corrupção, de morte e isolamento, de medo etc.

${ }^{25} \mathrm{O}$ texto da nota foi, em ação de retorno, dito simplista, porque ignorante da multifatoriedade, da multi ou interdisciplinaridade etc.

Recebido em 02 de agosto de 2008 Aceito para publicação em 11 de outubro de 2008 